\title{
LIMBAH BANDENG (Chanos chanos Forsskal) SEBAGAI SUMBER PROTEIN PENGGANTI TEPUNG IKAN DALAM PAKAN UDANG GALAH (Macrobracium rosenbergii de Man)
}

\section{Replacement of Fish Meal with Milkfish Waste Meal in Giant Shrimp (Macrobracium rosenbergii de Man) Feed Formula}

Arning Wilujeng Ekawati $1^{*}$, Muhammad Fakhri ${ }^{1}$, Joko Abdillah ${ }^{1}$ dan Wiwit Nor Indahsari ${ }^{1}$

${ }^{1}$ Fakultas Perikanan dan Ilmu Kelautan, Universitas Brawijaya, Malang

*ar_ning2000@ub.ac.id

\begin{abstract}
Abstrak
Penelitian ini bertujuan untuk menentukan jumlah terbaik pemanfaatan tepung limbah bandeng (Chanos chanos) sebagai sumber protein pengganti tepung ikan dalam pakan udang galah ( $M$. rosenbergii de Man). Penelitian ini menggunakan Rancangan Acak Lengkap (RAL) dengan 5 perlakuan dan 3 ulangan. Pakan yang digunakan sebagai perlakuan adalah pakan iso protein 35\% dan iso energi 3,40 kkal/g dengan perbedaan subtitusi protein tepung limbah bandeng terhadap tepung ikan, yaitu: (A) $0 \%$; (B) 25\%; (C) 50\%; (D) 75\%; dan (E) $100 \%$. Parameter yang diamati dan dianalisis terdiri dari: kelulushidupan, laju pertumbuhan spesifik, rasio konversi pakan, rasio efisiensi protein, dan retensi protein pada udang galah ( $M$. rosenbergii de Man). Hasil penelitian menunjukkan bahwa pemanfaatan tepung limbah bandeng sebagai sumber protein hewani pengganti tepung ikan dengan persentase yang berbeda dalam formula pakan tidak berpengaruh nyata terhadap semua parameter yang diamati pada udang galah ( $M$. rosenbergii de Man). Berdasarkan hasil penelitian dapat disimpulkan bahwa pemanfaatan tepung limbah bandeng dapat menggantikan tepung ikan sebagai sumber protein dalam pakan udang galah (M. rosenbergii de Man) hingga 100\%.
\end{abstract}

Kata kunci: Limbah bandeng, Pertumbuhan, Retensi protein, Udang galah (M. rosenbergii de Man)

\section{Abstract}

The purpose of this study was to determine the best amount of utilization of milkfish waste meal to replace fish meal in giant prawn (Macrobracium rosenbergii de Man) feed formula. This study used a completely randomized design (CRD) with 5 treatments and 3 replications. Five feeds (35\% iso-protein and $3.40 \mathrm{kcal} / \mathrm{g}$ isoenergy) were formulated with fishmeal protein replaced by milkfish waste meal protein. The replacements were A $(0 \%), \mathrm{B}(25 \%), \mathrm{C}(50 \%), \mathrm{D}(75 \%)$ and E (100\%) of fishmeal protein. The parameters observed and analyzed were survival rate, specific growth rate, feed conversion ratio, protein efficiency ratio, and protein retention. The results showed that the treatments did not affect all parameters. Based on the results, it can be concluded that the milkfish waste meal protein can replace fishmeal protein up to $100 \%$ in the feed formula of giant prawn (Macrobracium rosenbergii) de Man.

Keywords : Milkfish waste, Protein replacement, Macrobracium rosenbergii de Man

\section{PENDAHULUAN}

Komoditas hasil perikanan air tawar yang sangat potensial karena memiliki nilai ekonomi tinggi adalah udang galah $(M$. rosenbergii. de Man) Indonesia menduduki peringkat pertama sebagai negara pengekspor udang galah ke Amerika Serikat sebesar 22,7\% dengan nilai devisa mencapai US\$ 93,5 juta (Ashari et al., 2016). Produksi udang pada tahun 2014 yaitu 592.219 ton/tahun dan kenaikan rata rata produksi dari tahun 2010 hingga tahun 2014 adalah $13,83 \%$ dengan jumlah permintaan ekspor 141.041 ton/tahun
(KKP, 2018). Spesies ini dapat dibudidayakan di kolam air tawar, danau, bahkan di muara-muara sungai yang dipengaruhi oleh pasang surut (Abidin, 2011).

Rana et al. (2009) dan Pramana et al. (2019) menjelaskan bahwa dalam budidaya, pakan membutuhkan lebih dari $50 \%$ biaya produksi. Salah satu sumber protein dalam pembuatan pakan udang adalah tepung ikan. Pada periode 2000- 2005 harga tepung ikan berkisar antara US \$ 500 dan US \$700 per ton. Di bulan Mei 2008, harga tepung ikan US \$ 1210 per ton. Sampai saat ini 
harga tepung ikan masih mahal. Oleh karena itu perlu alternatif pengganti dari bahan yang memiliki nilai gizi tinggi namun harganya murah. Hal yang sama telah dikemukakan oleh Prawira et al. (2014).

Salah satu alternatif yang dapat digunakan sebagai sumber protein pengganti tepung ikan adalah limbah bandeng. Limbah bandeng mudah ditemukan terutama di daerah Jawa Timur. Menurut Hastarini et al. (2012), produk olahan bandeng sangat potensial untuk dikembangkan dan dapat ditemui paling banyak di Jawa Timur dengan potensi 108.385 ton/tahun, Jawa Barat 74.680 ton/tahun, dan Jawa Tengah 64.038 ton/tahun. Semakin banyaknya produsen bandeng olahan ini, maka semakin banyak pula limbah bandeng yang dihasilkan.

Ikan bandeng memiliki gizi yang tinggi yaitu $129 \mathrm{kkal}$ energi, $20 \mathrm{~g}$ protein (Purnomowati et al., 2006). Menurut Adawiyah dan Selviastuti (2014), tulang ikan bandeng mengandung protein $32 \%$, kalsium 4\% dan fosfor 3\%. Purba (2001) telah membuktikan bahwa pakan dengan penggunaan limbah jeroan ikan bandeng ( $40 \%$ usus, $15 \%$ jeroan, $5 \%$ insang dan $35 \%$ tulang) dengan perbandingan 50\%:50\% sebagai pengganti tepung ikan memberikan pengaruh yang baik terhadap pertumbuhan ikan nila. Pemanfaatannya pada jenis udang perlu dipelajari lebih lanjut. Penelitian ini bertujuan untuk menentukan jumlah terbaik pemanfaatan tepung limbah bandeng (Chanos chanos) sebagai sumber protein pengganti tepung ikan dalam pakan udang galah (M. rosenbergii de Man).

\section{METODOLOGI \\ Waktu dan Tempat}

Penelitian ini di Fakultas Perikanan dan Ilmu Kelautan, Universitas Brawijaya, Malang.

\section{Materi Penelitian}

Alat-alat yang digunakan dalam penelitian adalah akuarium ukuran $70 \times 40$ x $30 \mathrm{~cm}$, blower, selang aerasi, batu aerasi, heater akuarium, DO meter merek Lovibond, $\mathrm{pH}$ meter, timbangan analitik, spektrofotometer merek Thermo Spectronic HELIOS $\alpha$, jangka sorong, penggaris, seser, baskom, ayakan bertingkat, loyang, mortar dan alu, labu destruksi, soxhlet, oven, petri dish, cawan porselen, kompor listrik, pendingin balik, muffle merek Nabertherm, destilator, titrasi set, corong, penggiling pakan, desikator, crucible tongs, beaker glass, erlenmeyer, blender, nampan, panci kukus, kain saring dan alat pres.

Bahan yang digunakan dalam penelitian ini adalah udang galah $(M$. rosenbergii de Man) berat rata-rata 1 gram, tepung ikan, tepung kedelai, tepung dedak, tepung jagung, tepung limbah jeroan bandeng (Chanos chanos Forsskal), tepung tapioka, mineral vitamin mix, CMC, tablet Kjeldahl, petroleum eter, $\mathrm{H}_{2} \mathrm{SO}_{4}$, asam borat $3 \%, \mathrm{NaOH}$, etanol $96 \%$, akuades, methyl orange, aluminium foil, kertas label, dan silica gel.

\section{Rancangan Penelitian}

Metode yang digunakan adalah metode eksperimen menggunakan Rancangan Acak Lengkap yang terdiri dari 5 perlakuan dan 3 ulangan. Lima perlakuan pakan iso protein $35 \%$ dan iso energi 3,40 $\mathrm{kkal} / \mathrm{g}$ dengan perbedaan substitusi protein tepung limbah bandeng terhadap tepung ikan, yaitu: (A) $0 \%$; (B) $25 \%$; (C) $50 \%$; (D) 75\%; dan (E) 100\% (Tabel 1). Denah penelitian disajikan pada Gambar 1 .

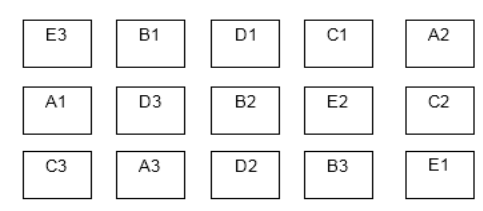

Gambar 1. Denah penempatan akuarium penelitian.

Keterangan:

A, B, C, D, E : Perlakuan

$1,2,3$ : Ulangan 
Tabel 1. Formula pakan penelitian.

\begin{tabular}{lccccc}
\hline Komposisi Bahan & $\mathrm{A}(0 \%)$ & $\mathrm{B}(25 \%)$ & $\mathrm{C}(50 \%)$ & $\mathrm{D}(75 \%)$ & $\mathrm{E}(100 \%)$ \\
\hline T. Ikan & 23,77 & 17,83 & 11,89 & 5,94 & 0,00 \\
T. Limbah Bandeng & 0,00 & 6,27 & 12,54 & 18,81 & 25,08 \\
T. Kedelai & 44,17 & 44,17 & 44,17 & 44,17 & 44,17 \\
T. Jagung & 7,24 & 7,24 & 7,24 & 7,24 & 7,24 \\
Dedak & 10,86 & 10,86 & 10,86 & 10,86 & 10,86 \\
Tapioka & 4,66 & 3,91 & 3,16 & 2,41 & 1,66 \\
Premix & 3 & 3 & 3 & 3 & 3 \\
CMC & 6,30 & 6,72 & 7,14 & 7,57 & 7,99 \\
\hline Total (g) & 100,00 & 100,00 & 100,00 & 100,00 & 100,00 \\
\hline Kadar Kering & 87,19 & 87,04 & 87,63 & 88,23 & 86,07 \\
Protein & 35,52 & 34,72 & 35,47 & 35,62 & 36,30 \\
Lemak & 7,79 & 7,95 & 7,21 & 6,82 & 7,82 \\
Kadar Abu & 9,68 & 9,07 & 9,64 & 9,24 & 9,57 \\
Serat Kasar & 4,84 & 6,16 & 5,39 & 6,28 & 6,43 \\
BETN & 42,17 & 42,10 & 42,29 & 42,04 & 39,88 \\
DE (kkal/100g) & 380,87 & 378,83 & 375,93 & 372,02 & 375,10 \\
GE (kkal/100g) & 467,04 & 469,16 & 464,03 & 463,81 & 468,87 \\
\hline
\end{tabular}

\section{Prosedur Kerja}

Kegiatan penelitian diawali dengan menimbang juvenil udang galah sebagai bobot awalnya (Wo), kemudian diambil sampel udang dan dilakukan analisis proksimat untuk mengetahui kadar protein, lemak dan energi awal. Pemberian pakan dilakukan dengan pakan perlakuan sebanyak 5\% dari total biomassa per hari dengan frekuensi sebanyak 3 kali sehari pada pukul $07.00,15.00$ dan 20.00 WIB dengan proporsi $30 \%$ (pagi), 30\% (siang), $40 \%$ (sore). Udang disampling sebanyak 4 kali, selama 45 hari pemeliharaan. 1 kali sebelum ditebar, dan setiap 15 hari udang disampling lagi untuk mengetahui pakan yang dibutuhkan dengan menimbang bobot tubuh.

Pengamatan pertumbuhan setiap 15 hari sekali meliputi bobot tubuh (Wt) dengan menimbang semua udang tiap akuarium dan penyesuaian pakan untuk 15 hari berikutnya. Pada akhir penelitian, sampel daging udang dilakukan analisis proksimat untuk mengetahui kadar protein, lemak dan energi udang di akhir masa pemeliharaan.

Pergantian air dilakukan setiap hari pada pukul 18.00 WIB untuk menjaga kualitas air tetap baik selama penelitian.
Pergantian air dilakukan dengan menyipon air akuarium sebanyak $30-40 \%$ dan menggantinya dengan air baru. Pengukuran suhu, $\mathrm{pH}$ dan $\mathrm{DO}$ air pemeliharaan dilakukan setiap hari sebelum disipon pada pagi dan siang hari pukul 06.00 dan 14.00 WIB.

\section{Parameter Uji}

Parameter utama yang diamati yaitu kelulushidupan, laju pertumbuhan, rasio pemberian pakan, dan rasio efisiensi protein udang galah (M. rosenbergii de Man) yang dipelihara selama 45 hari.

Survival Rate (SR) adalah kelulushidupan pada ikan yang dipelihara. Survival Rate (SR) ikan dapat dihitung dengan rumus Hastuti et al. (2016) sebagai berikut :

$\mathrm{SR}=\frac{\mathrm{Nt}}{\mathrm{No}} \times 100 \%$

Keterangan:

SR : Survival Rate (\%)

$\mathrm{N}_{\mathrm{t}} \quad$ : Jumlah ikan pada akhir pemeliharaan

No : Jumlah ikan pada awal pemeliharaan

Specific Growth Rate (SGR) merupakan persentase penambahan bobot setiap hari selama penelitian. Menurut Stead dan Laird (2002), SGR dapat dihitung dengan rumus sebagai berikut : 
$\mathrm{SGR}=\frac{\ln \mathrm{FBW}-\ln \mathrm{IBW}}{\mathrm{D}} \times 100 \%$

Keterangan:

SGR : Specific Growth Rate (\%BB/hari)

FBW: Bobot rata-rata pada akhir penelitian (g)

IBW : Bobot rata-rata pada awal penelitian (g)

D : Periode pemeliharaan (hari)

Feed Conversion Ratio (FCR) dapat dihitung dengan rumus sebagai berikut (Djarijah, 1995):

$\mathrm{FCR}=\frac{\mathrm{F}}{\mathrm{Wt}-\mathrm{Wo}}$

Keterangan:

F : Jumlah total pakan yang diberikan selama pemeliharaan $(\mathrm{g})$

Wo : Bobot total ikan awal pemeliharaan (g)

Wt : Bobot total ikan akhir pemeliharaan (g)

Protein Efficiency Ratio (PER) dihitung untuk mengetahui seberapa besar bobot yang dihasilkan dari seberapa banyak protein yang dikonsumsi oleh hewan uji. Menurut Mudambi (2001), PER dapat dihitung dengan rumus sebagai berikut :

PER $=\frac{\text { Pertambahat bobot ikan }(\mathrm{g})}{\text { Protein yang dikonsumsi }(\mathrm{g})}$

Retensi Protein (RP) dihitung menggunakan rumus berikut:

$\mathrm{RP}=\frac{\Sigma \mathrm{Pt}-\Sigma \mathrm{Po}}{\Sigma \mathrm{PP}} \mathrm{x} 100 \%$

Keterangan:

RP : Retensi protein (\%)

$\sum \mathrm{P} 0$ : Jumlah protein tubuh awal penelitian (g)

$\sum \mathrm{Pt}:$ Jumlah protein tubuh akhir penelitian (g)

$\sum \mathrm{PP}$ : Jumlah protein pakan (g)

Parameter penunjang yang diukur pada penelitian ini adalah kualitas air. Adapun parameter kualitas air yang diamati meliputi suhu, $\mathrm{pH}, \mathrm{DO}$, salinitas dan TAN. Pengukuran suhu dilakukan dengan menggunakan termometer, pengukuran $\mathrm{pH}$ menggunakan $\mathrm{pH}$ meter, pengukuran $\mathrm{DO}$ menggunakan DO meter, pengukuran salinitas menggunakan refraktometer, dan pengukuran amonia menggunakan spektrofotometer.

\section{Analisis Data}

Data yang telah dikumpulkan dari hasil penelitian kemudian dianalisis dengan analisis keragaman (ANOVA) sesuai dengan rancangan penelitian yang digunakan yaitu Rancangan Acak Lengkap (RAL). Jika dari data sidik ragam antar perlakuan menunjukkan pengaruh nyata atau berbeda nyata $(\mathrm{P}<0,05)$, maka dilanjutkan dengan uji BNT (Beda Nyata Terkecil) untuk membandingkan nilai antar perlakuan.

Kemudian dari uji ini dilanjutkan dengan uji polynomial ortogonal untuk mengetahui jumlah pemanfaatan limbah bandeng sebagai sumber protein pengganti tepung ikan yang terbaik terhadap kelulushidupan dan pertumbuhan pada udang galah ( $M$. rosenbergii de Man). Adapun analisis data dilakukan dengan bantuan program IBM SPSS Statistic 20.1.

\section{HASIL DAN PEMBAHASAN \\ Pertumbuhan Ikan dan Tanaman Kangkung}

Hasil pengukuran parameter utama selama penelitian disajikan dalam Tabel 2 berikut.

Tabel 2. Rata-rata $( \pm \mathrm{SD})$ hasil pengukuran parameter utama.

\begin{tabular}{|c|c|c|c|c|c|}
\hline \multirow{2}{*}{$\begin{array}{c}\text { Parameter } \\
\text { Utama }\end{array}$} & \multicolumn{5}{|c|}{ Perlakuan } \\
\hline & A & B & $\mathrm{C}$ & D & $\mathrm{E}$ \\
\hline SR (\%) & $\begin{array}{l}63,59 \\
\pm 6,41\end{array}$ & $64,62 \pm 6,41$ & $63,08 \pm 1,54$ & $67,18 \pm 0,89$ & $69,23 \pm 1,54$ \\
\hline SGR (\%BB/hr) & $2,08 \pm 0,36$ & $1,45 \pm 0,23$ & $1,69 \pm 0,28$ & $2,14 \pm 0,30$ & $2,18 \pm 0,33$ \\
\hline FCR & $1,93 \pm 0,45$ & $2,81 \pm 0,34$ & $2,57 \pm 0,41$ & $2,00 \pm 0,42$ & $2,02 \pm 0,42$ \\
\hline PER & $1,51 \pm 0,31$ & $1,04 \pm 0,12$ & $1,12 \pm 0,17$ & $1,45 \pm 0,33$ & $1,41 \pm 0,33$ \\
\hline RE (\%) & $23,30 \pm 5,28$ & $16,18 \pm 2,54$ & $18,56 \pm 2,88$ & $23,50 \pm 4,63$ & $23,62 \pm 5,45$ \\
\hline
\end{tabular}


Kelulushidupan dapat diartikan sebagai persentase perbandingan organisme yang hidup pada akhir pemeliharaan dengan jumlah organisme yang ditebar pada awal pemeliharaan dalam suatu wadah (Setiawati et al., 2013; Wahono et al., 2019).

Data dari Tabel 2 dapat dilihat bahwa nilai kelulushidupan udang galah $(M$. rosenbergii de Man) tertinggi yaitu pada perlakuan $\mathrm{E}$ sebesar $69,23 \%$ dan untuk persentase terendah yaitu pada perlakuan C sebesar 63,08\%. Perlakuan E dan D menunjukkan nilai kelulushidupan yang lebih tinggi dibandingkan dengan perlakuan A, B dan C.

Hal ini diduga karena dipengaruhi oleh faktor kanibalisme karena apabila dilihat dari udang yang sudah mati, sebagian besar sudah dalam kondisi yang sudah tidak utuh. Sesuai dengan pernyataan
Hoanh et al. (2010), bahwa faktor yang mempengaruhi kelulushidupan udang di antaranya yaitu persaingan atau kanibalisme. Hal ini juga diperkuat oleh pernyataan New dan Valenti (2000), yang menyatakan bahwa predasi dan kanibalisme merupakan faktor yang tidak bisa dihindari dalam budidaya udang galah, sehingga kepadatan saat penebaran harus sangat diperhatikan.

Pertumbuhan mutlak ikan nila pada sistem akuaponik selama 37 hari pemeliharaan mencapai rata-rata pertambahan panjang $3,31 \mathrm{~cm}$ dan pertambahan bobot 21,59 gram.

Data hasil pertumbuhan mutlak tanaman kangkung selama pemeliharaan dengan menggunakan sistem akuaponik disajikan pada Tabel 3.

Tabel 3. Pertumbuhan mutlak tanaman kangkung.

\begin{tabular}{lccc}
\hline Parameter & Awal & Akhir & Hasil Pertumbuhan \\
\hline Panjang (cm) & $9,14 \pm 1,04$ & $57 \pm 2,75$ & $47,86 \pm 2,81$ \\
Bobot $(\mathrm{g})$ & $0,23 \pm 0,03$ & $17,08 \pm 2,73$ & $16,85 \pm 2,74$ \\
\hline
\end{tabular}

Faktor kanibalisme terjadi diduga karena pakan perlakuan masih kurang mengandung mineral terutama kalsium. Pada penelitian ini, pakan yang dibuat mengandung abu/mineral tidak lebih dari $10 \%$, sedangkan pada penelitian Hossain et al. (2010), pakan percobaan yang digunakan untuk memelihara udang galah memiliki kandungan mineral sebesar 1214\%. Mineral dibutuhkan oleh udang selama proses ganti kulit (molting), karena selama ganti kulit, eksoskeleton yang banyak mengandung mineral akan hilang. Mineralisasi pada cangkang akan meningkat melalui penambahan kalsium dalam pakan (Sumeru dan Anna, 1992).

Proses molting yang terhambat akan meningkatkan faktor kanibalisme karena udang berada dalam kondisi rentan dalam kurun waktu yang lama. Data hasil penelitian secara keseluruhan menunjukkan bahwa nilai kelulushidupan udang galah ( $M$. rosenbergii de Man) pada masingmasing unit perlakuan tergolong rendah, yaitu di bawah 70\%. Seperti pernyataan New et al. (2010), kelulushidupan yang baik bagi pemeliharaan udang air tawar yaitu antara $75-80 \%$.

Laju pertumbuhan dapat diartikan sebagai pertambahan bobot makhluk hidup dalam kurun waktu tertentu. Sedangkan laju pertumbuhan spesifik dihitung untuk mengetahui pertumbuhan bobot biota per hari. Menurut Buwono (2000) dan Aunurrofiq et al. (2019), cepat atau tidaknya pertumbuhan ikan atau udang, ditentukan oleh banyaknya protein yang dapat diserap dan dimanfaatkan oleh tubuh sebagai zat pembangun. Kesimpulan bahwa laju pertumbuhan spesifik tertinggi diperoleh perlakuan E yaitu sebesar 2,18 $\% \mathrm{BB} /$ hari, sedangkan nilai laju pertumbuhan udang galah (M. rosenbergii de Man) terendah diperoleh perlakuan B yaitu sebesar 1,45\%BB/hari.

Hasil laju pertumbuhan masingmasing unit percobaan pada penelitian ini masih tergolong rendah apabila 
dibandingkan dengan penelitian yang dilakukan oleh Sobirin (2016) yaitu nilai laju pertumbuhan spesifik udang galah tertinggi pada unit percobaannya sebesar $2,517 \% \mathrm{BB} /$ hari. Hal ini diduga karena pakan pada masing-masing perlakuan masih kurang mengandung karbohidrat dan persentase berat kering yang masih rendah. Pakan pada penelitian ini mengandung BETN sebesar 28-31\%, serta persentase berat kering sebesar $86-87 \%$, sedangkan proksimat pakan udang galah pada penelitian Hossain et al. (2000) mengandung BETN sebesar 31-34\% serta persentase berat kering lebih dari $90 \%$.

Halver (1972) menyatakan bahwa idealnya pertumbuhan ikan atau udang akan setara dengan kandungan kalori, protein, atau setidaknya kadar kering bahan dari suatu pakan. Udang galah merupakan hewan omnivora atau pemakan segala, namun lebih cenderung herbivor. Menurut Parnata (2004), hewan herbivor atau omnivora dapat mengonsumsi karbohidrat dalam jumlah besar. Karbohidrat merupakan sumber energi ketiga setelah protein dan lemak.

\section{Rasio Konversi Pakan}

Rasio konversi pakan yaitu perbandingan antara jumlah pakan yang diberikan dengan pertambahan bobot ikan selama penelitian. Dengan rasio ini dapat diketahui kebutuhan pakan untuk menghasilkan bobot ikan yang diinginkan. Rasio Konversi Pakan akan mempengaruhi kualitas pakan, ukuran serta kondisi ikan (Parker, 2011).

Hasil perhitungan rasio konversi pakan udang galah (M. rosenbergii de Man) pada masing-masing perlakuan selama masa pemeliharaan 45 hari menunjukkan bahwa rasio konversi pakan terendah diperoleh perlakuan A yaitu sebesar 1,93, sedangkan nilai tertinggi diperoleh perlakuan B yaitu sebesar 2,81.

Nilai FCR yang rendah pada perlakuan A diduga karena ikan mampu memanfaatkan pakan dengan baik jika dibandingkan dengan perlakuan yang lain.
Seperti pernyataan Djarijah (1995), bahwa pakan yang dapat dimanfaatkan dengan baik akan menghasilkan nilai FCR yang semakin rendah. Baiknya pemanfaatan pakan oleh unit percobaan A diduga karena pakan A memiliki kandungan serat kasar 5,94 \% paling mendekati dengan kebutuhan udang galah. Seperti pernyataan New et al. (1995), bahwa kandungan serat kasar yang optimal dalam pakan untuk udang air tawar yaitu 3,5 $-4,5 \%$.

Tingginya rata-rata kandungan serat kasar secara keseluruhan pada pakan perlakuan yaitu, diduga menyebabkan tingginya nilai FCR pada penelitian ini. Seperti pernyataan Ghufran dan Kordi (2010), bahwa kandungan serat kasar yang tinggi dalam pakan ikan dan udang akan mempengaruhi daya cerna dan penyerapan di dalam pencernaan ikan, selain itu juga akan mengurangi kualitas pakan. Apabila dibandingkan dengan penelitian yang dilakukan oleh Langer et al. (2011), yang menggunakan EWM (Earth Worm Meal) sebagai substitusi tepung ikan untuk udang galah, yaitu nilai FCR rata-rata sebesar 0,86 , begitu pula dengan penelitian Muralisankar et al. (2014) yang menggunakan penambahan minyak sayur dalam formulasi pakan udang galah, yaitu nilai FCR terendahnya sebesar 1,72.

Rasio efisiensi protein merupakan banyaknya protein yang dimanfaatkan udang dari pakan yang diberikan, rasio efisiensi protein adalah perbandingan antara pertambahan bobot ikan dengan jumlah protein yang diberikan dalam pakan. Rasio ini dapat digunakan sebagai tolok ukur kualitas pakan, semakin tinggi nilai rasio efisiensi proteinnya, maka pakan tersebut semakin baik.

Hasil perhitungan rasio efisiensi protein pakan pada masing-masing perlakuan dengan masa pemeliharaan udang galah ( $M$. rosenbergii de Man) selama 45 hari, dapat disimpulkan bahwa rasio konversi protein tertinggi diperoleh perlakuan A yaitu sebesar 1,51, sedangkan 
nilai terendah diperoleh perlakuan B yaitu sebesar 1,04 .

Hasil perhitungan rasio efisiensi protein pada perlakuan A menunjukkan hasil yang paling tinggi dibandingkan dengan perlakuan lain, hal ini diduga karena pakan perlakuan A yang merupakan $100 \%$ tepung ikan memiliki kandungan asam amino yang merupakan senyawa penyusun protein yang lebih tinggi dan kompleks. Menurut New dan Valenti (2000), untuk mendapatkan efisiensi pakan yang optimal, pakan udang galah harus mengandung asam amino yang cukup tinggi yang dapat menjadi faktor pembatas dalam bahan pakan sebagai sumber protein, seperti arginin, lisin, dan metionin.

$$
\text { Retensi protein merupakan }
$$

banyaknya protein yang disimpan pada tubuh dan dimanfaatkan untuk membangun jaringan tubuh yang baru dan memperbaiki sel - sel yang rusak oleh ikan. Retensi Protein tertinggi pada perlakuan E yaitu sebesar 23,62 $\pm 5,45 \%$ dan diikuti perlakuan D $(23,50 \pm 4,63 \%)$, perlakuan A $(23,30 \pm 5,28 \%)$, perlakuan C $(18,56 \pm$ $2,88 \%)$, dan perlakuan B (16,18 $\pm 2,54 \%)$. Kadar retensi protein pada udang galah $(M$. rosenbergii) tertinggi pada perlakuan $\mathrm{E}$, diduga karena adanya pertambahan bobot tubuh yang tinggi sehingga pemanfaatan protein dalam tubuh udang juga tinggi dibanding perlakuan yang lain.

Menurut Buwono (2000) dan Tantri et al. (2019), penambahan lisin pada, pertumbuhan diasumsikan sebagai pertambahan jaringan struktural, yang berarti peningkatan jumlah protein dalam jaringan tubuh. Cepat tidaknya pertumbuhan udang, ditentukan oleh banyaknya protein yang dapat diserap dan dimanfaatkan oleh tubuh udang sebagai zat pembangun. Hampir semua jaringan secara aktif mengikat asam-asam amino dan menyimpannya secara intraseluler dalam konsentrasi yang lebih besar, untuk dibentuk menjadi protein tubuh (sel-sel tubuh).

Ariesta et al. (2015) menyatakan bahwa jumlah protein yang tercerna akan

meningkat dengan meningkatnya kandungan protein pakan. Hal ini sejalan dengan penelitian yaitu pada pakan $\mathrm{E}$ (substitusi 100\%) menghasilkan retensi protein yang tinggi, atau dikatakan protein yang dicerna oleh ikan untuk dimanfaatkan dalam maintenance dan pertumbuhannya juga tinggi. Pernyataan Suhenda et al. (2005) menyatakan adanya kecenderungan naiknya retensi protein dengan naiknya kadar protein pakan karena protein memegang peranan penting dalam pembentukan struktur atau jaringan tubuh.

Kualitas air memiliki peran yang penting dalam kegiatan budidaya. Berdasarkan hasil selama penelitian, suhu diperoleh berkisar antara $27,96-28,98^{\circ} \mathrm{C}$. Hal ini sesuai dengan pernyataan Boyd dan Zimmerman (2000), kisaran suhu metabolik optimum untuk $M$. rosenbergii adalah antara $26^{\circ} \mathrm{C}-32^{\circ} \mathrm{C}$. Udang air tawar atau udang galah ( $M$. rosenbergii) berhenti tumbuh dan mungkin tidak bertahan dalam waktu lama ketika suhu air di bawah $19^{\circ} \mathrm{C}$ atau di atas $34^{\circ} \mathrm{C}$.

Masa pemeliharaan selama 45 hari, kisaran kadar oksigen terlarut yaitu 5,32 $5,48 \mathrm{mg} / \mathrm{L}$. pada kisaran ini masih dalam batas wajar untuk kelangsungan hidup udang galah ( $M$. rosenbergii). Hal ini sejalan dengan yang dijelaskan Cheng et al. (2003), kandungan oksigen terlarut yang optimal untuk udang galah berkisar 3-7 $\mathrm{mg} /$ liter, dan menimbulkan stres jika di bawah $2 \mathrm{mg} /$ liter.

Kisaran $\mathrm{pH}$ selama masa pemeliharaan adalah 6,95-6,97. Nilai pH tersebut masih termasuk wajar dalam pemeliharaan udang galah (M. rosenbergii). Hal ini sesuai dengan pernyataan Hadie dan Hadie (2002), kisaran optimal pH air yang mendukung kehidupan juvenil udang galah dengan baik yaitu pada $6,8-8,5$.

Menurut Mallasen dan Valenti (2006), konsentrasi nitrit yang ideal bagi pemeliharaan larva udang galah adalah < 0,1 ppm. Pada penelitian, kadar nitrit tidak melebihi batas ideal, yaitu berkisar 0,05 $0,07 \mathrm{mg} / \mathrm{l}$. Pada konsentrasi DO yang tinggi, pembentukan nitrit akan 
berlangsung lebih cepat (Komarawidjaya, 2006).

Hasil akhir proses nitrifikasi adalah terbentuknya nitrat. Senyawa N anorganik ini relatif tidak bersifat racun bagi kehidupan udang dibanding dengan amonia dan nitrit (Komarawidjaya, 2006). Kadar nitrat rata - rata selama masa pemeliharaan berkisar $0,04-0,07 \mathrm{mg} / \mathrm{l}$. Kondisi nitrat di perairan yang optimal untuk budidaya udang $<0,1$ ppm (Vijayakumaran et al., 2010).

Menurut Boyd (1990), kadar NH3 untuk pertumbuhan udang galah yang baik adalah kurang dari $0,09 \mathrm{mg} / \mathrm{L}$ dan pada kadar $0,45 \mathrm{mg} / \mathrm{L}$ menyebabkan penurunan pertumbuhan udang jenis penaeid. Selama masa pemeliharaan, kadar NH3 didapat pada kisaran $0,05 \mathrm{mg} / \mathrm{l}$. TAN dan nitrit yang tinggi dalam perairan bersifat berbahaya bagi ikan. Persentase amonia bebas meningkat dengan meningkatnya nilai $\mathrm{pH}$ dan suhu perairan (Tacon et al., 2009).

\section{KESIMPULAN DAN SARAN Kesimpulan}

Hasil penelitian ini mengamati dan menganalisis kelulushidupan, laju pertumbuhan spesifik, rasio konversi pakan, rasio efisiensi protein, dan retensi protein maka dapat disimpulkan bahwa tepung limbah bandeng dapat digunakan sebagai sumber protein hewani pengganti tepung ikan dalam formula pakan (M. rosenbergii de Man) sampai $100 \%$.

\section{Saran}

Hasil penelitian dapat disarankan bahwa tepung limbah bandeng dapat digunakan sebagai sumber protein pengganti tepung ikan dalam formula pakan (M. rosenbergii de Man) sampai 100\%.

\section{DAFTAR PUSTAKA}

Abidin, J., 2011. Penambahan Kalsium untuk Meningkatkan Kelulusan Hidup dan Pertumbuhan Juvenil Udang Galah (Macrobrachium rosenbergii de Man) pada Media
Bersalinitas, Doctoral dissertation, Institut Pertanian Bogor, Bogor.

Adawiyah, A.R. dan Selviastuti, R., 2014. Serburia Suplemen Tulang Ikan Bandeng dengan Cangkang Kapsul Alginat Untuk Mencegah Osteoporosis. Jurnal Ilmiah Mahasiswa, 4(1), pp. 53-59.

Ariesta, A.H., Mahardika, I.G. dan Dewi, G.A.M.K., 2015. Pengaruh level energi dan protein ransum terhadap penampilan ayam kampung umur 010 minggu. Majalah Ilmiah Peternakan 18 (3): 89 - 94.

Aunurrofiq, A., Prayogo, P. dan Arief, M., 2019. Substitusi fermentasi limbah padat surimi ikan swanggi (priacanthus macracanthus) pada tepung ikan terhadap retensi protein dan retensi lemak ikan lele dumbo (Clarias sp.). Journal of Aquaculture and Fish Health, 6(3), pp.121-128

Ashari, U., Sahara, S. dan Hartoyo, S., 2016. Daya saing udang segar dan udang beku Indonesia di negara tujuan ekspor utama. Jurnal Manajemen \& Agribisnis, 13(1), p.1.

Boyd, C. dan Zimmerman, S., 2000. Chapter 14. Grow-Out SystemsWater Quality and Soil Management. Freshwater prawn culture: the farming of Macrobrachium rosenbergii, Blackwell Scienc. Oxford. pp 221-238.

Boyd, C.E., 1990. Water Quality In Ponds For Aquaqulture. Birmingham Publishing CO. Birmingham. pp 451. Buwono I.D., 2000. Kebutuhan Asam Amino Esensial Dalam Ransum Ikan, Kanisius. Yogyakarta, p. 56.

Cheng, W., Liu, C.H. dan Kuo, C.M., 2003. Effects of dissolved oxygen on hemolymph parameters of freshwater giant prawn, Macrobrachium rosenbergii (de Man). Aquaculture, 220(1-4), pp.843-856.

Djarijah, A.S., 1995. Pakan Ikan Alami. Kanisius. Yogyakarta. p. 61.

Ghufran, M. dan Kordi, K., 2010. Panduan Lengkap Memelihara Ikan Air Tawar 
di Kolam Terpal. Lily Publisher. Yogyakarta. pp. 280.

Hadie, W. dan Hadie, L.E., 2002. Pembenihan Udang Galah (Macrobrachium rosenbergii de Man) Usaha Industri Rumah Tangga. Kanisius. Yogyakarta. p. 110.

Halver, J.E., 1972. Fish Nutrition. Academic Press. New York. 699 pp.

Hastarini, E., Fardiaz, D., Irianto, H.E. dan Budjianto, S., 2012. Karakteristik minyak ikan dari limbah pengolahan filet ikan patin siam (Pangasius hypopthalmus) dan patin jambal (Pangasius djambal). agritech, 32(4), pp. $403-410$.

Hastuti, Y.P., Yudistira, C., Nirmala, K., Nurusallam, W. dan Faturochman, K., 2016. Addition of $\mathrm{CaCO} 3$ to culture media at the salinity of $3 \mathrm{~g} / \mathrm{L}$ for freshwater tambaqui growth. Jurnal Akuakultur Indonesia, 15(1), pp.3240.

Hoanh, C.T., Szuster, B.W., Pheng, K.S., Ismail, A.M. and Noble, A.D., 2010. Tropical Deltas and Coastal Zones, Food Production, Communities and Environment at the Land-Water Interface. $\mathrm{CAB}$ International, London, 459 pp.

Hossain, M.A., Siddique M.A.L. and Miaje, M.A.H., 2000. Development of lowcost feed for culture of giant freshwater prawn (Macrobrachium rosenbergii) in ponds. Bangladesh Journal Fish Research, 4(2), pp. 127134.

Kementerian Kelautan dan Perikanan, KKP., 2018. Produktivitas Perikanan Indonesia. Pada : Forum Merdeka Barat 9 Kementerian Komunikasi dan Informatika.

Komarawidjaya, W., 2006. Pengaruh perbedaan dosis oksigen terlarut (DO) pada degradasi amonium kolam kajian budidaya udang. Jurnal Hidrosfir Indonesia, 1(1), pp. 32 - 37.

Langer, S., Bakhtiyar, Y. and Lakhnotra, R., 2011. Replacement of fishmeal with locally available ingredient in diet composition of Macrobrachium dayanum. African Journal of Agricultural Research, 6(5), pp. 1080-1084.

Mallasen, M. dan Valenti, W.C., 2006. Effect of nitrite on larval development of giant river prawn Macrobrachium rosenbergii. Aquaculture, 261(4), pp. 1292-1298.

Mudambi, S.R., 2001. Fundamentals of Foods and Nutrition. New Age International Publishers. $402 \mathrm{hlm}$.

Muralisankar, T., Bhavan, P.S., Radhakrishnan, S., Seenivasan, C., Manickam, N. and Shanti, R., 2014. Effects of dietary supplementation of fish and vegetable oils on the growth performance and muscle compositions of the freshwater prawn Macrobrachium rosenbergii. The Journal of Basic and Applied Zoology, 67(2), pp. 34-39.

New, M.B. and Valenti, W.C., 2000. Freshwater Prawn Culture: the Farming of Macrobrachium rosenbergii. Blackwell Science Ltd. London. 435 pp.

New, M. B., Tacon, A.G.J. and Imre, C., 1995. Farm-made Aquafeeds (No. 343). FAO Fisheries Departments. Rome. 429 pp.

New, M.B., Valenti, W.C., Tidwell, J.H., D'Abramo, L.R. and Kutty, M.N., 2010. Freshwater Prawns, Biology and Farming. Blackwell Publishing Ltd. $531 \mathrm{pp}$.

Parker, R., 2011. Aquaculture Science. Cenange Learning. New York. pp 322.

Parnata, A.S., 2004. Pupuk Organik Cair Aplikasi dan Manfaatnya. Agromedia. Jakarta. pp. 112.

Pramana, A., Agustono, A. dan Nurhajati, T., 2019. Penambahan lisin pada pakan komersial terhadap laju pertumbuhan, rasio konversi pakan dan efisiensi pakan udang galah (Macrobrachium rosenbergii). Journal of Aquaculture and Fish Health, 7(1), pp.18-24. 
Prawira, M.A., Sudaryono A. dan Rachmawati, D., 2014. Penggantian tepung ikan dengan tepung kepala lele dalam pakan terhadap efisiensi pemanfaatan pakan dan pertumbuhan juvenil udang vaname (Litopenaeus vannamei). Journal of Aquaculture Management and Technology, 3(4), pp. $1-8$.

Purba, R. M., 2001. Pemanfaatan silase limbah jeroan ikan nila sebagai substitusi tepung ikan dalam pakan ikan nila gift (Oreochromis sp.). Skripsi. Program Studi Budidaya Perairan Fakultas Perikanan dan Ilmu Kelautan, Institut Pertanian Bogor. Bogor, p. 57.

Rana, K.J., Siriwarddena, S. and Hasan, M.R., 2009. Impact of Rising Feed Ingredient Prices on Aquafeeds and Aquaculture Production (No. 541). Food and Agriculture Organization of the United Nations. Rome. 78 pp.

Purnomowati, I., Hidayati, D. dan Saparinto, C., 2006. Ragam Olahan Bandeng. Kanisius. Yogyakarta. 80 hlm.

Setiawati, J.E., Tarsim, Adiputra, Y.T. dan Hudaidah, S., 2013. Pengaruh penambahan probiotik pada pakan dengan dosis berbeda terhadap pertumbuhan, keluilushidupan, efisiensi pakan dan retensi protein ikan patin (Pangasius hypophthalmus). e-Jurnal Rekayasa dan Teknologi Budidaya Perairan, 1(2), pp. $151-162$.

Sobirin, M., 2016. Pengaruh penambahan cod liver oil (CLO) pada pakan komersial terhadap laju pertumbuhan, rasio konversi pakan dan efisiensi pakan udang galah (Macrobrachium rosenbergii).

Skripsi. Fakultas Perikanan dan Kelautan, Universitas Airlangga, Surabaya. p. 85.

Stead, S.M. and Laird, L., 2002. The handbook of Salmon Farming. Springer-Praxis Publishing. UK. 321 pp.
Suhenda, N., Setijaningsih, L. dan Suryanti, Y., 2005. Pertumbuhan benih ikan patin jambal (Pangasius djambal) yang diberi pakan dengan kadar protein berbeda. Berita Biologi, 7(4), pp. $191-197$.

Sumeru, S.U. dan Anna, S., 1992. Pakan Udang Windu (Panaeus monodon). Kanisius. Jakarta. $93 \mathrm{hlm}$.

Tacon, A.G.J., Metian, M. dan Hasan, M.R., 2009. Feed ingredients and fertilizers for farmed aquatic animals: sources and composition (No. 540). Food and Agriculture Organization of the United Nations (FAO). Roma. pp 209.

Tantri, A.F., Rahardja, B.S. dan Agustono, A., 2019. Penambahan lisin pada pakan komersial terhadap retensi protein dan retensi energi udang galah (Macrobrachium rosenbergii). Journal of Aquaculture and Fish Health, 5(2), pp.78-84

Vijayakumaran, M., Anbarasu, M. dan Kumar, T.S., 2010. Moulting and growth in communal and individual rearing of the spiny lobster, Panulirus homarus. J. Mar. Biol. Ass. India, 52 (2), pp. 274-281.

Wahono, F., Agustono, A. dan Lamid, M., 2019. Efek penambahan 1-karnitin pada pakan terhadap laju pertumbuhan benih lobster air tawar (Cherax qudricarinatus). Journal of Aquaculture and Fish Health, 3(1), pp.8-12. 